\title{
Effect of Pre-sowing Magnetic Field Treatment on Some Biochemical and Physiological Processes in Faba Bean (Vicia faba L. spp. Minor)
}

\author{
Anna Podleśna ${ }^{1} \cdot$ Jolanta Bojarszczuk ${ }^{2}$ (D) Janusz Podleśny ${ }^{2}$
}

Received: 4 August 2018 / Accepted: 19 December 2018 / Published online: 18 February 2019

(c) The Author(s) 2019

\begin{abstract}
The aim of this paper was to determine the changes in some biochemical and physiological processes, which occurred in seeds and seedlings of faba bean and to evaluate the germination dynamics and plant emergence after pre-sowing seeds treatment with a magnetic field. The study was carried out on Petri dishes in climatic chambers of the company HERAEUS (Germany). Each plate was lined with filter paper and 80 seeds of faba bean were sown. The paper was sprayed with the same amount of distilled water in each plate. Treatment of seeds significantly increased the activity of amylolytic enzymes in faba bean seeds and seedlings. The greatest differentiation in enzymatic activity between stimulated and nontreated seeds was noted after $96 \mathrm{~h}$ from the time of sowing. Seeds treated with the magnetic field showed greater dynamics of weight at the time of imbibition than nontreated seeds. Treating of seeds with a magnetic field considerably increased the amount of indole-3-acetic acid and gibberellic acid in germinating seeds, above-ground parts and in roots of faba bean seedlings. The pre-sowing treatment with a magnetic field had favorable effects on the growth and development of seedlings.
\end{abstract}

Keywords Faba bean $\cdot$ Magnetic field $\cdot$ Stimulation of seeds $\cdot$ Enzyme activity $\cdot$ IAA $\cdot \mathrm{GA}_{3}$

\section{Introduction}

An important factor in crops is the quality of seeds that determines their germination and the vigor of seedlings grown from them (Rochalska 2002). Therefore, some studies are currently being conducted with various methods for seed improvement (Florez et al. 2007; Khawar et al. 2010; Marinkoviæ et al. 2008; Perveen et al. 2011; Zia et al. 2012). Recently, more attention has been paid to physical factors, which may be used in the process of seed preparation (Delibatlova and Ivanova 2006; Hernandez et al. 2010; Gładyszewska 2011; Govindaraj et al. 2017; Samuilov and Garifullina 2007; Szajsner et al. 2017). The prevailing view is that physical factors stimulating seeds to germinate act only on the course of physiological and biochemical

Jolanta Bojarszczuk

jbojarszczuk@iung.pulawy.pl

1 Department of Plant Nutrition and Fertilization, Institute of Soil Science and Plant Cultivation - State Research Institute, Czartoryskich Str. 8, 24-100 Puławy, Poland

2 Department of Forage Crop Production, Institute of Soil Science and Plant Cultivation - State Research Institute, Czartoryskich Str. 8, 24-100 Puławy, Poland processes which occur in them, and therefore, they are safe for the environment (Govindaraj et al. 2017; Jamil et al. 2012; Podleśny 1998; Podleśny et al. 2003, 2004). One of the physical factors that may be used in the stimulation of germination as well as growth and development of seedlings is a magnetic field (Rochalska 2005; Pietruszewski and Wójcik 2000; Pietruszewski and Martinez 2015). Literature reports indicate the mainly positive effects of treating seeds with a magnetic field, which is often referred to as magnetic stimulation for growth, development and yield of some cereal, maize, sunflower and vegetable species (Florez et al. 2007; Martinez et al. 2009; Zepeda-Bautista et al. 2014). Based on them, it can be concluded that particular species, and even varieties, respond to a different extent to the magnetic field, and the effects depend largely on the magnetic field parameters determined by the magnetic induction value. There is a lack of research on the impact of magnetic fields on faba bean seeds, their germination and the further growth of plants. Conducting such a study in this species seems to be particularly justified due to the relatively low and variable yields over the years, often due to high sensitivity to weather conditions and poor seeding quality resulting, among others, from the high susceptibility of beans to diseases and pests. 
The aim of this study was to determine the effect of presowing seed treatment with a magnetic field on changes of some biochemical and physiological processes in seeds and seedlings of faba bean as well as on the germination dynamics and plant emergence.

\section{Materials and Methods}

\section{Experimental Conditions}

The study was conducted in the Institute of Soil Science and Plant Cultivation-State Research Institute in Puławy [51 $\left.24^{\circ} 59^{\prime \prime} \mathrm{N} 21^{\circ} 58^{\prime} 09^{\prime \prime} \mathrm{E}\right]$, Poland.

Experiment was performed on Petri dishes in climatic chambers of the company HERAEUS (Germany). Each plate (diameter $150 \mathrm{~mm}$ ) was lined with filter paper and 80 seeds of faba bean Tim variety were sown. The germination capacity of seeds was $92 \%$, thousand seed weight-624 g and humidity $-14 \%$. The paper in each pot was sprayed with $170 \mathrm{ml}$ of distilled water. Air humidity in the climatic chamber was $90 \%$, air temperature $24^{\circ} \mathrm{C}$, and light intensity 10,000 lx.

\section{Experimental Factors}

The experimental factor was three doses of magnetic field intensity: $D_{0}$-no stimulation (control), $D_{1}-10,750$ $\mathrm{Jm}^{-3} \mathrm{~s}(B=30 \mathrm{mT}, s=15 \mathrm{~s}), D_{2}-85,987 \mathrm{Jm}^{-3} \mathrm{~s}(B=85 \mathrm{mT}$, $s=15 \mathrm{~s})$. Magnetic stimulation of seeds was performed at the Department of Physics at the University of Life Science in Lublin, using a specially designed device for pre-sowing seed treatment with a magnetic field (Fig. 1), equipped with

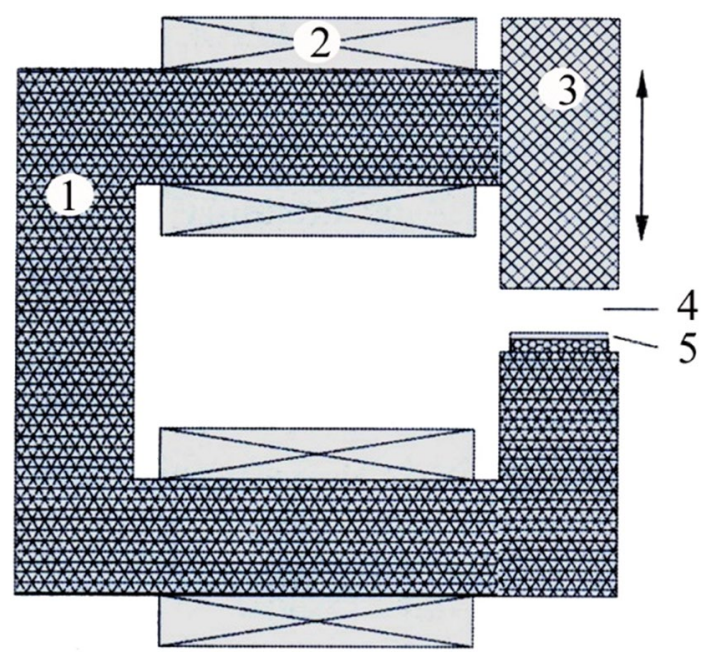

Fig. 1 Block diagram of electromagnet (1-magnetic core, 2-field coils, 3-mobile magnetic core, 4-air gap, 5-seed sample) an electromagnet powered by $50 \mathrm{~Hz}$ with a smooth regulation of magnetic induction (Pietruszewski and Kornarzyński 1999). The basic element of this device is an electromagnet consisting of a core made of transformer steel with wound windings. The moving part of the core allows for smooth adjustment of the gap width changes. Thanks to this adjustment a smooth change in magnetic induction in the range from 30 to $100 \mathrm{mT}$ was possible.

\section{Amylolytic Enzyme Determination}

Evaluation of amoylolytic enzyme activity as well as IAA and $\mathrm{GA}_{3}$ content was performed at the Institute of Rural Medicine in Lublin. The seeds, previously subjected to magnetic stimulation, were placed on Petri dishes and then analyzed at the following eight terms: $0,24,48,72,96,120$, 144 and $168 \mathrm{~h}$ after magnetic field stimulation. Enzyme activity was determined based on the amount of glucose released from starch by the complex of enzymes contained in the supernatant. This supernatant was obtained by adding $5 \mathrm{ml}$ of acetate buffer with $\mathrm{pH} 4.8$ and containing $20 \mu \mathrm{mol}$ $\mathrm{CaCl}_{2}$ to $0.5 \mathrm{~g}$ of dried plant material and then the mixture was centrifuged for $10 \mathrm{~min}$ at $3000 \mathrm{rpm}$. The amount of $0.5 \mathrm{ml}$ of starch solution at $0.5 \%$ concentration was added to $0.5 \mathrm{ml}$ of the supernatant and hydrolyzed at $37^{\circ} \mathrm{C}$ for $10 \mathrm{~min}$. The glucose content was determined by the modified Somogyi-Nelson method (1952), most often used in biochemical tests for determining the content of reducing sugars. This method uses the color reduction of the arsenic-molybdenum reagent with cuprous ions formed in the solution as a result of the reaction of the copper reagent with reducing sugars. The intensity of the color was determined by colorimetry on a DRLANGE Tricolor LFM3 instrument (Dr Bruno Lange Gm\# Berlin, Germany) at the wavelength $\lambda=520 \mathrm{~nm}$. The instrument was run on program 9, with $X=07630, Y=07910$ and $Z=09680$. Milled samples (4 g) were placed in a $45 \mathrm{~mL}$ glass cell calibrated over a white tile background. Measurements were made in duplicates to obtain the CIELAB $L^{*} a^{*} b^{*}$ values ( $L=$ luminosity, $a=$ red component, $b=$ blue component). The content of reducing sugars was determined on the basis of the calibration curve made for glucose solutions.

\section{IAA and $\mathrm{GA}_{3}$ Determination}

IAA content was determined by HPLC and the modified Hardin and Stutte (1981) method. The analytical procedure was described in detail by Podleśny (2002). The content of $\mathrm{GA}_{3}$ was determined at the Institute of Rural Medicine in Lublin, by the high-pressure HPLC method (highperformance liquid chromatography) (Hardin and Stutte 1981; Hirosava 1989). The analyses were performed on the HP-1050 liquid chromatograph. $10 \mathrm{~g}$ of acetone solution and 
water in a ratio of 2:1 were added to $10 \mathrm{~g}$ of pre-ground plant mass. Then, the mixture was crushed in a mortar and stored for $1 \mathrm{day}$, at $+4{ }^{\circ} \mathrm{C}$ in a sealed bottle. The content of the flask was filtered through a sintered glass, and the obtained filtrate was concentrated on a vacuum evaporator to a volume of less than $20 \mathrm{ml}$ per $1 \mathrm{~g}$ of dry matter. The solution was then poured into containers, supplemented with distilled water to a volume of $20 \mathrm{ml}$ per $1 \mathrm{~g} \mathrm{~d}$.m. and frozen at $-20{ }^{\circ} \mathrm{C}$. Then, the solution was successively thawed and centrifuged by withdrawing two times for $5 \mathrm{ml}$ of the supernatant. Fifty $\mu \mathrm{l}$ of acetonitrile was added to the first portion and $50 \mu \mathrm{l}$ of acetonitrile containing 10,000 ng IAA and $36,000 \mathrm{ng} \mathrm{GA}_{3}$ to the other. Both batches were acidified to $\mathrm{pH} 2$ with $10 \% \mathrm{HCl}$ and esterified twice with $5 \mathrm{ml}$ of a mixture of butanol and methyl acetate in the ratio 1:1. The extracts were evaporated in a vacuum to dryness (bath temperature $40^{\circ} \mathrm{C}$ ) and the residue was dissolved in $10 \mathrm{ml}$ of $20 \%$ solution of methanol in water. The obtained solutions were passed through DOWEX $1 \times 8$ 100-200 Mesch anion exchange columns, vol. $1 \mathrm{ml}$. Then, they were rinsed with $10 \mathrm{ml}$ of a $20 \%$ methanol solution and with $10 \mathrm{ml}$ of $0.2 \mathrm{~N}$ sodium acetate $-80 \mathrm{ppm}$. and methanol -20 parts. (V: V). Next, $20 \mathrm{ml}$ of a mixture of acetic acid and methanol (1:1) was added to each effluent which was then concentrated on an evaporator to dryness (bath temperature $40{ }^{\circ} \mathrm{C}$ ). In the next stage to the obtained residue was added $500 \mu$ of the mobile phase and $20 \mu \mathrm{m}$ of it was dispensed into the loop in a liquid chromatograph. $\mathrm{GA}_{3}$ was determined on a UV detector at $254 \mathrm{~nm}$, a mobile phase $-0.15 \mathrm{M}$ zinc acetate, $0.05 \%$ acetic acid and $0.75 \%$ acetonitrile. The obtained graphs were compared to the planimetric pattern. Indole-3-acetic acid (IAA) was determined on an Ex 292 fluorescence detector, Em 362, mobile phase $\mathrm{MeOH}$, acetonitrile, 20/20/60 buffer (0.05 $\mathrm{M}$ acetic acid, $0.005 \mathrm{M}$ sodium acetate). ODS column Hypersil $5 \mu \mathrm{m} 200 \times 4.6 \mathrm{~nm}$. Concentration of IAA and $\mathrm{GA}_{3}$ was measured $168 \mathrm{~h}$ after sowing of seeds.

\section{Germination of Seeds and Biometric of Hypocotyl and Roots}

The Emergence Rate Index (Ed) was determined based on the following equation:

$\mathrm{Ed}=\frac{\mathrm{Ne}}{\mathrm{Ns}} \times 100 \%(\%)$

where $\mathrm{Ne}$ - the number of emerged seeds, Ns-the number of sown seeds.

Only normally germinating and fully developed seeds were counted.

Dry matter content in the seedlings was determined by drying in oven at $105{ }^{\circ} \mathrm{C}$, according to the gravimetric method (Wood and Roper 2000).

\section{Statistics}

The activity of amylolytic enzymes and the IAA content in the seeds and seedlings were determined in three series and four replications. Obtained data were processed statistically in the Statistica Program, v.13.1 at a significance level of $p \leq 0.05$.

\section{Results}

Treating the seeds with a magnetic field increased the activity of amylolytic enzymes in seeds and seedlings of faba bean. The course of changes in the activity of enzymes under the influence of the magnetic field occurred particularly in the final stage of germination, that is, in the period from 120 to $168 \mathrm{~h}$ after sowing seeds (Fig. 2). However, in the first days after sowing, the increase in enzyme activity was much smaller. The activity of the studied enzymes was increasing over time, reaching the highest value after $168 \mathrm{~h}$ from sowing. Both doses of the magnetic field induction caused a beneficial effect, although the higher dose $(85 \mathrm{mT})$ had a slightly stronger effect on the germination rate of faba bean seeds than the smaller one $(30 \mathrm{mT})$. The applied stimulation of seeds caused increased amylolytic enzyme activity (on

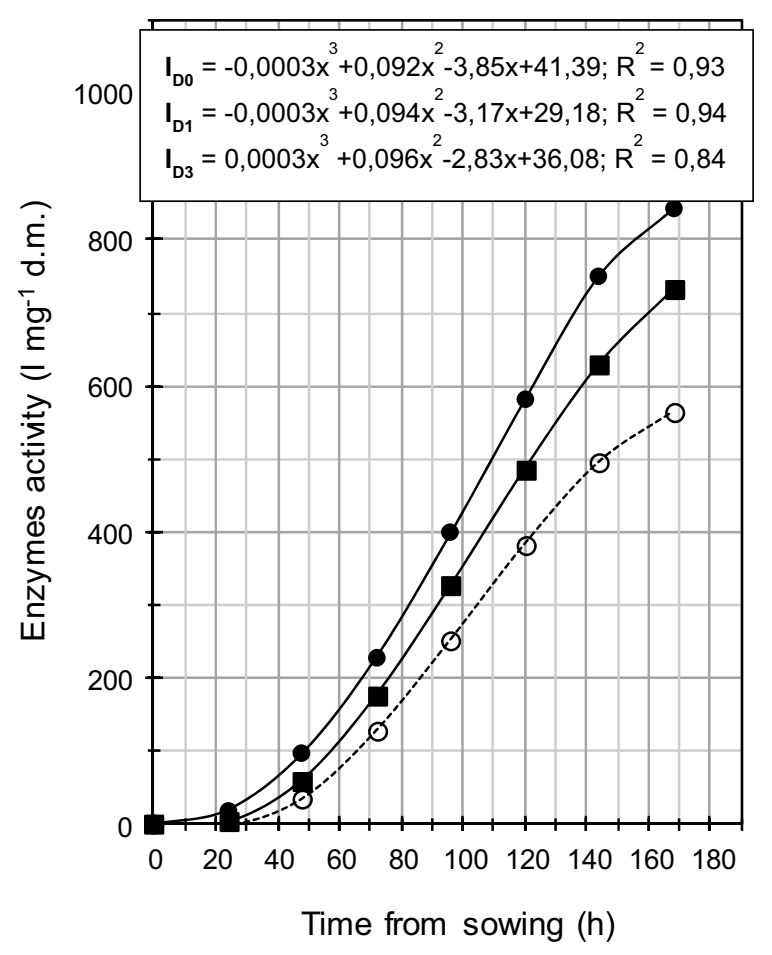

Fig. 2 The course of changes in the activity of amylolytic enzymes in faba bean seeds and seedlings treated and not treated with a magnetic field 


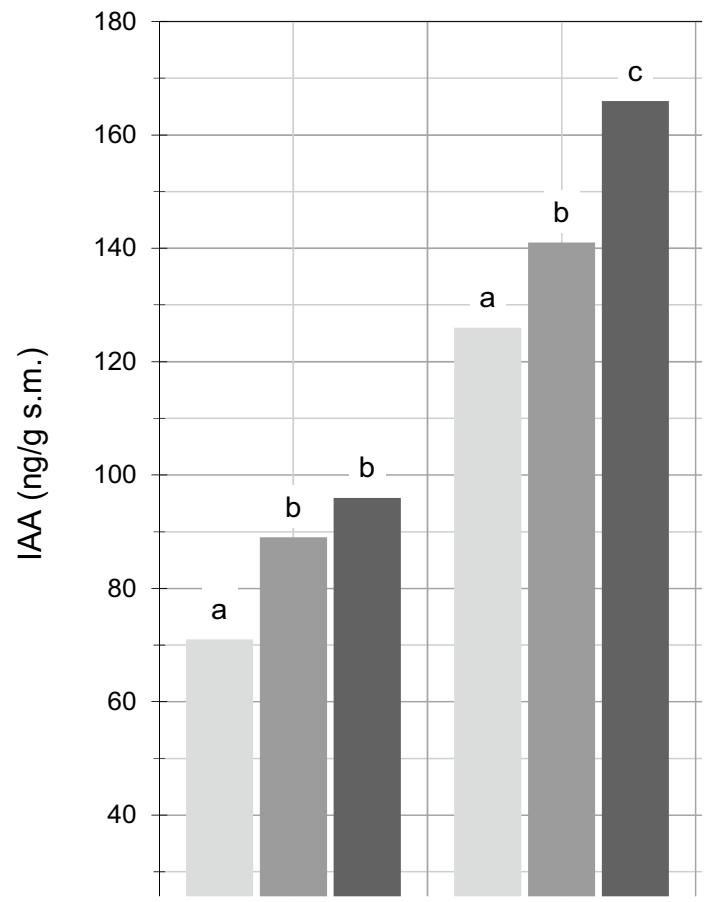

Fig. 3 The content of indole-3-acetic acid (IAA) in seeds, aboveground part and roots of faba beans depending on the dose of the magnetic field

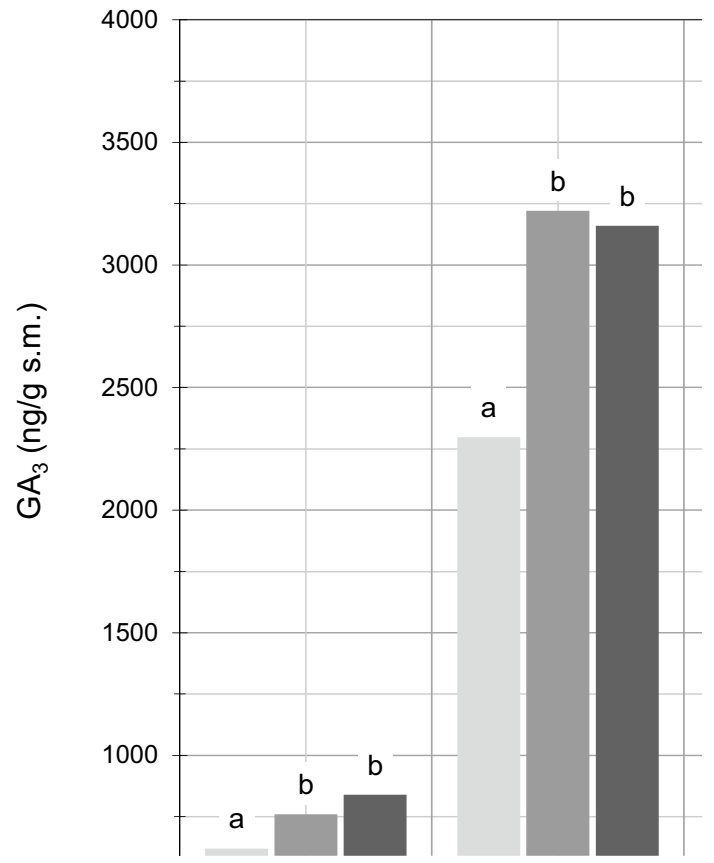

Fig. 4 The content of gibberellic acid (GA3) in seeds, above-ground part and roots of faba beans depending on the dose of the magnetic field average for both doses of magnetic field induction) at 24, $48,72,96,120,144$ and $168 \mathrm{~h}$ after sowing respectively by: $10,13,51,80,120,170,240$ and $275 \mathrm{I} \mathrm{mg}^{-1}$ d.m. Treating the seeds with a magnetic field considerably increased the amount of indole-3-acetic acid (IAA) and gibberellic acid $\left(\mathrm{GA}_{3}\right)$ in germinating seeds as well as in above-ground parts and in roots of young seedlings of faba bean in comparison to control (Figs. 3, 4). A higher content of IAA was found in seeds and above-ground parts of plants grown from the seeds treated with a higher dose of the magnetic field ( $85 \mathrm{mT})$. However, the higher content of these auxins in the roots occurred as a result of treating the seeds with a lower dose $(30 \mathrm{mT})$ of the magnetic field. Higher $\mathrm{GA}_{3}$ contents in above-ground parts and roots were shaped by a lower dose of the magnetic field $(30 \mathrm{mT})$, and contents in the seeds by the higher dose $(85 \mathrm{mT})$. The highest content of these phytohormones occurred in above-ground parts of young faba bean plants, where the greatest differences in the growth of these compounds were visible due to the magnetic stimulation of seeds. The application of two doses of magnetic field ( $D_{1}=35$ and $D_{2}=85 \mathrm{mT}$ ) did not differentiate the content of IAA and $\mathrm{GA}_{3}$ in the seeds and roots of faba bean plantlets. Significant differences in the content of these acids in seeds and roots occurred between the objects with use of seed biostimulation and control. Significant differences in the content of indolyl-3-acetic acid in aboveground parts of seedlings occurred only between the applied doses of the magnetic field. The magnetic field caused the increase of IAA content in germinating seeds, above-ground parts and roots of faba bean in relation to IAA content in organs of plants from control objects by: 21.5, 27.5 and $22.0 \mathrm{ng} / \mathrm{g}$ d.m., respectively, whereas the increase of $\mathrm{GA}_{3}$ content, respectively, by: 180, 892 and $239 \mathrm{ng} / \mathrm{g}$ d.m. Differences in the course of germination were observed already $24 \mathrm{~h}$ after sowing but the differentiation in germination dynamics of faba bean seeds was visible from 24 to $96 \mathrm{~h}$ after sowing. Plants grown from seeds subjected to the action of the magnetic field grew faster and more evenly compared to controls, however, the higher dose of the magnetic field gave better results than the lower one (Fig. 5). Control seeds and those subjected to the magnetic field completed the germination process after $168 \mathrm{~h}$ from sowing. Treatment of seeds with the magnetic field effected the initial growth and development of plants, which was observed as the increase of the length of roots and stems of faba bean plants (Figs. 6, 7). Both magnetic field doses significantly influenced the increase of the length and weight of roots. Seven days after sowing, $D_{1}$ and $D_{2}$ doses increased root length by 25.5 and $43.1 \%$, respectively, and the stem length, respectively, by 28.1 and $52.3 \%$ in relation to seedlings from the controls. Pre-sowing stimulation of seeds by the magnetic 
Fig. 5 The effect of magnetic field on the dynamics of seed germination

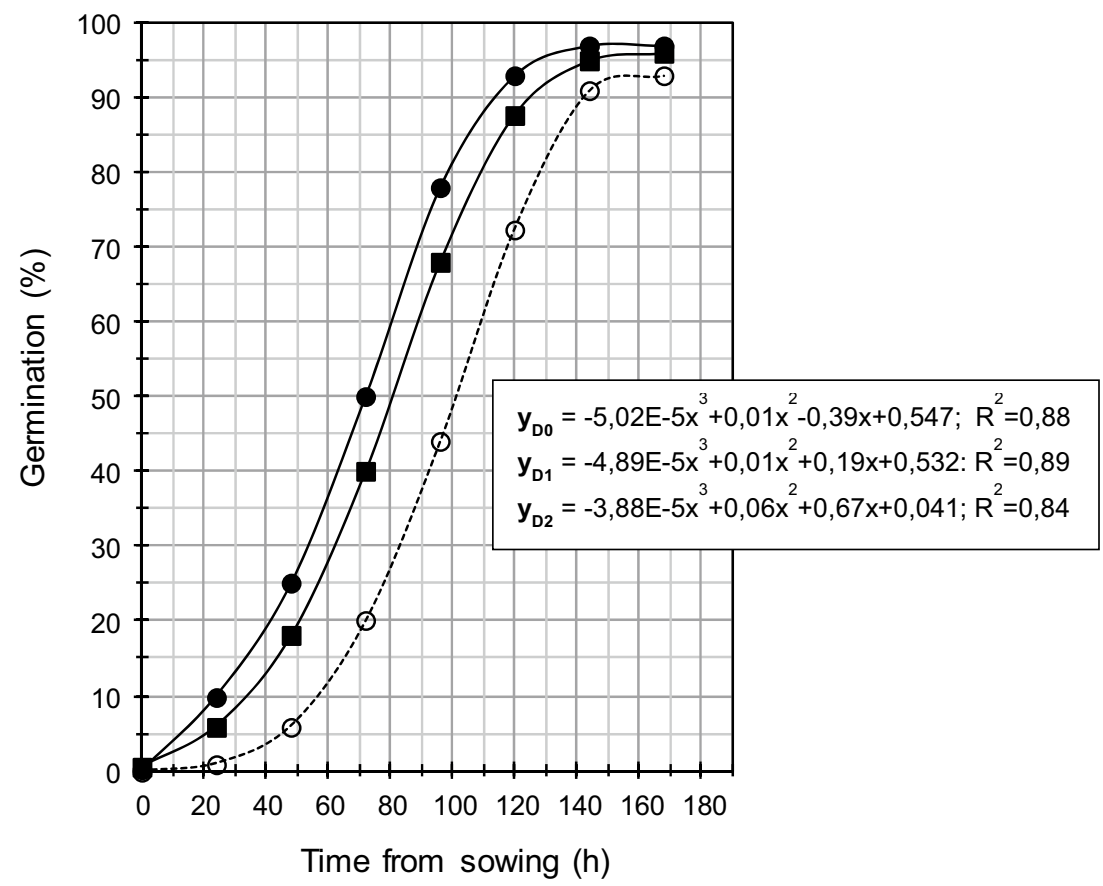

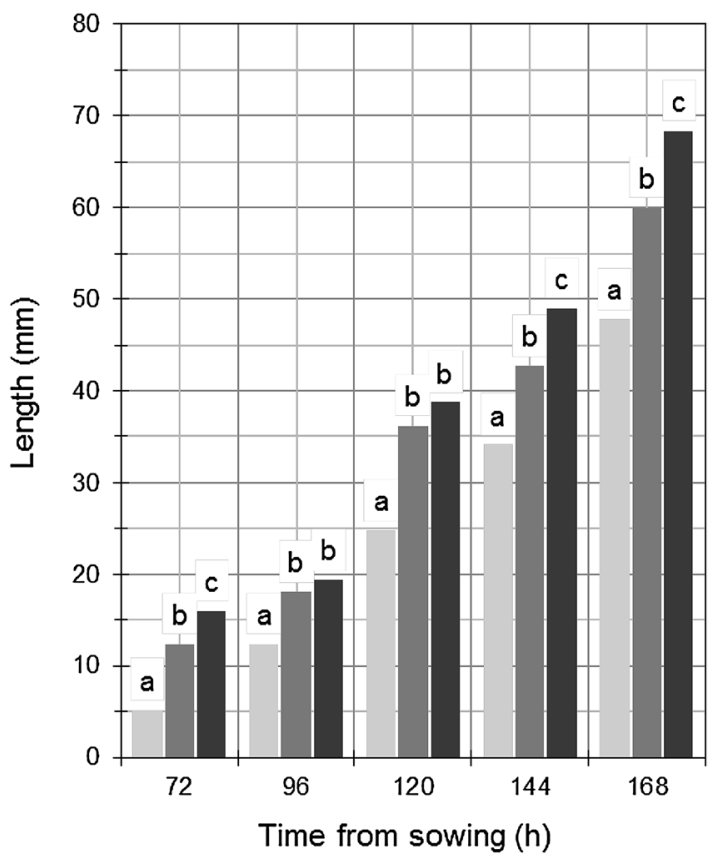

Fig. 6 The root length of faba bean seedlings grown from seeds treated with magnetic field

field significantly affected the rate of water absorption as well as the weight of swelling seeds and seedlings of faba bean (Fig. 8). Seeds previously treated with the magnetic field significantly increased their mass compared to seeds not treated with this factor. After $168 \mathrm{~h}$ from sowing, the average weight of one seedling grown from seeds not treated with a magnetic field was $1.14 \mathrm{~g}$, whereas the

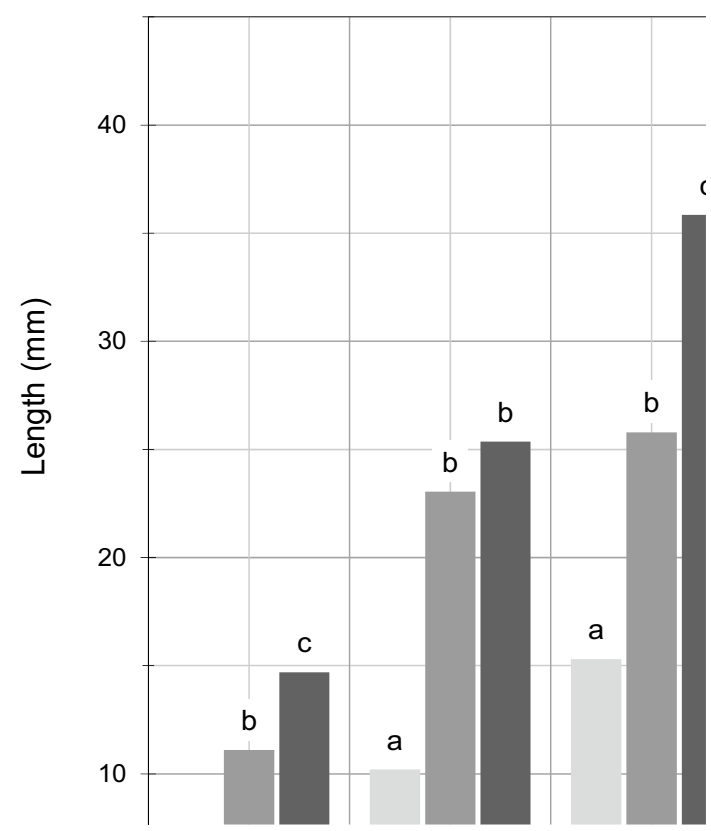

Fig. 7 The length of stems of faba bean grown from seeds treated and nontreated with magnetic field

mass of seedlings grown from seeds treated with a magnetic field with induction of 30 and $85 \mathrm{mT}$ amounted to 1.34 and $1.41 \mathrm{~g}$, respectively. This means that pre-sowing treatment of seeds with a magnetic field resulted in a faster weight increase of swelling seeds and seedlings of faba bean in relation to control seeds, because the field 


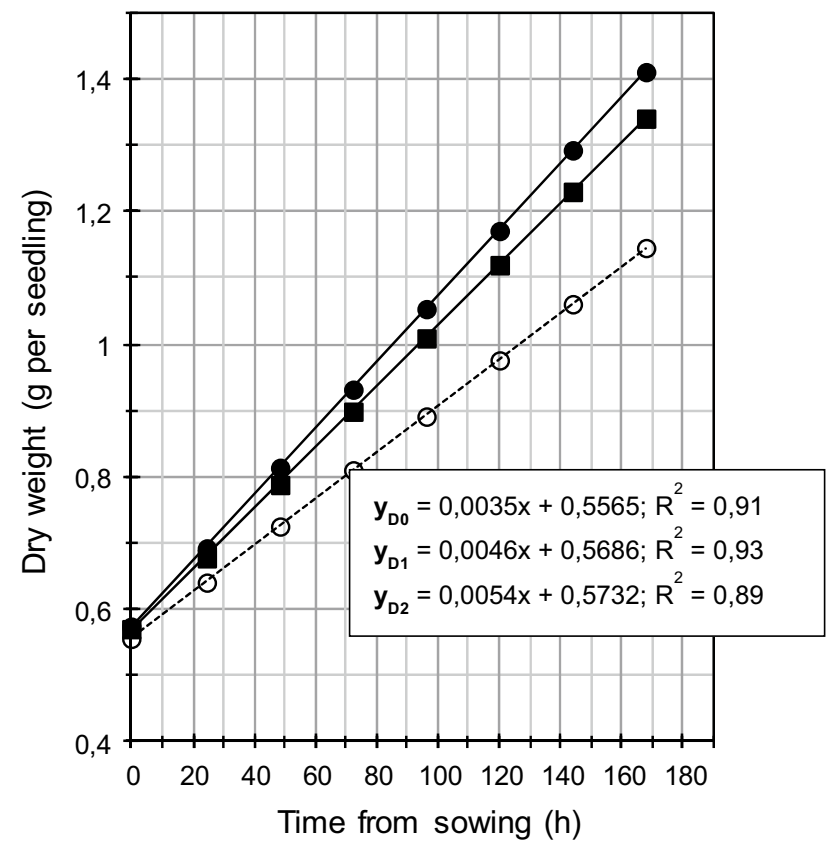

Fig. 8 The course of changes in the dry weight of seeds and seedlings of faba bean depending on exposure dose of magnetic field

induction doses 30 and $85 \mathrm{mT}$ increased the final seed weight by 17.2 and $23.5 \%$, respectively.

\section{Disscusion}

The studies showed that pre-sowing treatment with a magnetic field affected the course of analyzed physiological and biochemical processes. Changes in germination dynamics and in the growth of faba bean seedlings were observed. First of all, seeds treated with the magnetic field expressed higher activity of amylolytic enzymes which causes acceleration of the germination process in relation to untreated seeds. Then, higher doses of the magnetic field caused increased IAA and $\mathrm{GA}_{3}$ enzyme concentrations in seeds and seedlings. Podleśna et al. (2015) also showed significantly increased amylolytic enzyme activity as an effect of pre-sowing irradiation of pea seeds with laser light. According to Jakubowska (2004), the increase in IAA content may be caused by hydrolysis of IAA conjugates, whereas the level of reduction is the result of irreversible conjugation or oxidative hormone degradation. This indicates that the physical factors such as laser irradiation or magnetic fields are the external factors controlling the content of IAA in the seeds and affecting the mechanism of its action. It is especially important in the beginning phase of plant development because the main role of these compounds is stimulation of plant growth by enhancement of its elongation growth. Iqbal et al. (2012) reported that a magnetic field caused a significant increase in the germination rate of pea (Pisum sativum L. cv. Climax) seeds. According to those authors, the improved germination rate compared to untreated seeds was from 75.1 to $86.4 \%$ for the emergence index, from 1.89 to $13.2 \%$ for final emergence percentage and from 12.1 to $204.6 \%$ for vigor index. In studies of Szajsner et al. (2017), laser radiation and magnetic field significantly increased both the germination energy and capacity of sugar beet seeds. Mridha and Nagarajan (2014) reported a significant increase in seedling vigor and improved root characteristics in chickpea after magnetic treatment of its seeds. This also proved that the changes in the irradiated seeds cause changes in the dynamics of the development of the obtained seedlings (Delibaltova and Ivanova 2006; Hernandez et al. 2010). The results obtained by Garcia et al. (2013) concerning the application of a magnetic field on soybean seeds showed increased germinated seed numbers and seedling root lengths grown from the stimulated seeds. According to Aladjadjiyan (2007), more intensive growth of maize stems and yield, compared to control plants, were observed after use of magnetic field with 150 or $60-200$ $\mathrm{mT}$, respectively. Vashisth and Nagarajan (2010) found that pre-sowing magnetic field stimulation of sunflower seeds with $250 \mathrm{mT}$ caused not only faster germination but also an increase of seedling dry matter. Matwijczuk et al. (2012) confirmed a positive effect of magnetic field and magnetically treated water at the intensity of $30 \mathrm{mT}$ on the process of sunflower seed germination. Aladjadjiyan (2007) reported that maize plants showed the increase of steam in effect of a static magnetic field effect on seeds with intensity $150 \mathrm{mT}$. Simi et al. (2013) applied a magnetic field with intensities of 20, 40, 60, 80 and $100 \mathrm{mT}$ on chickpea seeds and the greatest increase of root and leaf length (depending on chickpea cultivar) was obtained in the case of seeds treated with 60 and $80 \mathrm{mT}$ as well as with 60 and $100 \mathrm{mT}$, respectively. In turn Mahajan and Pandey (2014) observed a positive effect of magnetic field induction with intensities of 87, 157, 194 and $226 \mathrm{mT}$ and $100 \mathrm{~min}$ of exposure. Those authors elaborated a new model called "the magnetic-time model", that is, the product of magnetic induction and of the exposure time. Pietruszewski and Martinez (2015) showed that alternating magnetic field $(35 \mathrm{mT})$ causes, relative to the control, a greater increase in germination capacity than the static field (100 and $185 \mathrm{mT}$ ). The paper of Nawroz and Hero (2010) and Iqbal et al. (2012) confirmed that a magnetic field stimulates the process of seed germination and plant development, as well as improves yield and quality. Novitskii et al. (2014) also found a significant effect of magnetic field application on radish seed germination, biophysical properties of seedlings as well as final yield of seeds. According to Hernandez et al. (2009), the effect of magnetic field application depends not only on its intensity but also on plant genotype.

The research carried out so far shows that some physical factors increase the vigor of seedlings, and later the 
growth dynamics of plants grown from them. According to Pietruszewski and Martinez (2015), the effect of magnetic induction was squared. The literature shows that the best results of seed stimulation with physical methods are obtained when the optimal exposure dose is applied. Small doses usually stimulate seed germination and the subsequent development of plants, whereas large doses may have a negative effect, and sometimes even cause mutations (Rybiński 1993). However, according to Pietruszewski (1999), determining the optimal dose of the magnetic field for a given species or variety is difficult. Therefore, before the field experiments, the optimal value of the exposure dose should be determined based on laboratory tests of seed germination, including the economic factor, that is, doses requiring the least amount of energy by the stimulation device should be selected. However, it is not known whether the magnetic field dose that is optimal for a given species or variety under laboratory conditions will be the best dose in field cultivation conditions. In the available literature there are no studies in which the doses of magnetic field exposure proved to be too high and the occurrence of negative stimulation effects found. It is, therefore, difficult to determine when the "overdose" may occur, which has been found in relation to some other physical factors. However, in the conducted studies, both applied doses of magnetic field had a positive effect on the growth of faba bean seedlings.

\section{Conclusions}

1. Treatment of seeds with a magnetic field significantly increased the activity of amylolytic enzymes in faba bean seeds and seedlings. The greatest difference in the enzymatic activity between stimulated and nontreated seeds was noted after $96 \mathrm{~h}$ from the sowing.

2. Seeds treated with the magnetic field showed greater dynamics of weight increase at the time of imbibition than untreated seeds.

3. Treating faba bean seeds with a magnetic field considerably increased the amount of indole-3-acetic acid (IAA) and gibberellic acid $\left(\mathrm{GA}_{3}\right)$ in germinating seeds as well as in the above-ground parts and roots of seedlings. The greatest differentiation of phytohormones content between stimulated and nontreated seeds was noted in the above-ground part of plants, whereas their contents in roots and seeds were significantly lower.

4. The pre-sowing seed treatment with a magnetic field had, in comparison to control, a positive effect on the growth and development of seedlings as well as their dry and fresh matter.

5. In the conducted studies, both applied doses of magnetic field had a positive effect on the analyzed proper- ties of faba bean seeds and seedlings. However, for some changes in the period of seed germination and growth of faba bean seedlings, the higher dose $\left(D_{2}\right)$ was better than the smaller one $\left(D_{1}\right)$.

Acknowledgements This research was financed by the Multi-Annual Program of Institute of Soil Science and Plant Cultivation - State Research Institute, task 2.3: Assessment and support the implementation of integrated production processes and technological progress in crop production (grain, forage and energy crops). This manuscript has not been published or presented elsewhere in part or in entirety, and is not under consideration by another journal. The study design was approved by the appropriate ethics review boards. All the authors have approved the manuscript and agree with submission to your esteemed journal. There are no conflicts of interest to declare.

Open Access This article is distributed under the terms of the Creative Commons Attribution 4.0 International License (http://creativeco mmons.org/licenses/by/4.0/), which permits unrestricted use, distribution, and reproduction in any medium, provided you give appropriate credit to the original author(s) and the source, provide a link to the Creative Commons license, and indicate if changes were made.

\section{References}

Aladjadjiyan A (2007) The use of physical methods for plant growing stimulation in Bulgaria. J Central Eur Agric 8(3):369-380

Delibaltova V, Ivanova R (2006) Impact of the pre-sowing irradiation of seeds by helium-neon laser on the dynamics of development of some cotton varieties. J Environ Prot Ecol 7(4):909-917

Florez M, Carbonell MV, Martinez E (2007) Exposure of maize seeds to stationary magnetic fields: effects on germination and early growth. Environ Exp Bot 59:68-75

Garcia AS, Reina FG, Franco YP, Paez DD (2013) Stimulation of germination and growth in soybean seeds by stationary magnetic field treatment. Asian J Agri Biol 1(2):85-90

Gładyszewska B (2011) Estimation of a laser biostimulation dose. Int Agrophys 25(4):403-405

Govindaraj M, Masilamani P, Alex Albert V, Bhaskaran M (2017) Effect of physical seed treatment on yield and quality of crops: a review. Agric Rev 38(1):1-14

Hardin JM, Stutte ChA (1981) Analysis of plant hormones using highperformance liquid chromatography. J Chrom 208:124-128

Hernandez AC, Dominguez-Pacheco A, Carballo Carballo A, CruzOrea A, Ivanom R, Lopez Bonilla Jl, Valcarcel Montoñez JP (2009) Alternating magnetic field irradiation on three genotype maize seed performance. Acta Agrophys 14(1):7-17

Hernandez AC, Dominguez PA, Cruz OA, Ivanov R, Caballo CA, Zepeda BR (2010) Laser in agriculture. Int Agrophys 24:407-422

Hirosava E (1989) Auxins induce $\alpha$-amylase activity in pea cotyledons. Plant Physiol 916:484-486

Iqbal M, Haq Z, Jamil Y, Ahmad MR (2012) Effect of presowing magnetic treatment on properties of pea. Int Agrophys 26:25-31

Jakubowska A (2004) The mechanism of IAA level regulation in plants. (in Polish). Mikołaj Kopernik University, Torun, 1-116

Jamil Y, Haq Z, Igbal M, Jamil T, Amin N (2012) Enhancement in growth and yield of mushroom (Pleurotus ostreatus) using magnetic field treatment. Int Agrophys 26(4):375-380

Khawar A, Bhatti IA, Khan HN, Bhatti HN, Sheikh MA (2010) A germination test: an easy approach to know the irradiation history of seeds. Pak J Agri Sci 47:279-285 
Mahajan TS, Pandey OP (2014) Magnetic-time model at off-season germination. Int Agrophys 28:57-62

Marinkoviæ B, Grujiæ M, Marinkoviæ D, Crnobarac J, Marinkoviæ J, Jaæimoviae G, Mircov DV (2008) Use of biophysical methods to improve yields and quality of agricultural products. J Agric Sci 53(3):235-241

Martinez E, Carbonell MV, Florez H, Amaya JM, Maqueda R (2009) Germination of tomato seeds (Lycopersicon esculantum $\mathrm{L}$.) under magnetic fields. Int Agrophys 23:44-50

Matwijczuk A, Kornarzyński K, Pietruszewski S (2012) Effect of magnetic field on germination and seedling growth of sunflower. Int Agrophys 26:271-278

Mridha N, Nagarajan S (2014) Effect of pre-sowing static magnetic seed treatment on germination and root characters in chickpea (Cicer arietinum L.). J Agric Phys 14(1):22-29

Nawroz ART, Hero FHK (2010) Impact of magnetic application on the parameters related to growth of chickpea (Cicer arietinum L.). JJBS 3(4):175-184

Novitskii YI, Novitskaya GV, Serdyukov YA (2014) Lipid utilization in radish seedlings as affected by weak horizontal extremely low frequency magnetic field. Bioelectromagnetics 35:91-99

Perveen R, Jamil Y, Ashraf M, Ali Q, Iqbal M, Ahmad MR (2011) He-Ne laser-induced improvement in biochemical, physiological, growth and yield characteristics in sunflower (Helianthus annuus L.). Photochem Photobilol 87:1453-1463

Pietruszewski S (1999) Magnetic biostimulation of material sowing of spring wheat (in Polish). Rozprawy Naukowe AR w Lublinie 220:1-55

Pietruszewski S, Kornarzyński K (1999) Magnetic biostimulation of wheat seeds. Int Agrophys 13:497-501

Pietruszewski S, Martinez E (2015) Magnetic field as a method of improving the quality of sowing material: a review. Int Agrophys 29:377-389

Pietruszewski S, Wójcik S (2000) Effect of magnetic field on yield and chemical composition of sugar beet roots. Int Agrophys 14:89-92

Podleśna A, Gładyszewska B, Podleśny J, Zgrajka W (2015) Changes at biochemical processes and yielding of pea as an effect of laser seeds irradiation. Int Agrophys 29:285-492

Podleśny J (1998) Wpływ przedsiewnego traktowania nasion promieniami laserowymi na rozwój i plonowanie bobiku (Vicia faba minor). Pam Puł 113:73-84

Podleśny J (2002) Studies on influence of laser light on seeds, growth, development and yielding of the white lupine (Lupinus album L.) plants (in Polish), 3. Monografie i Rozprawy Naukowe, IUNG, Puławy, pp 1-59

Podleśny J, Lenartowicz W, Sowiński M (2003) The effect of magnetic biostimulation on the formation of morphological features and yielding of different genotypes of white lupine (in Polish). Zesz Probl Post Nauk Rol 495:399-406

Podleśny J, Pietruszewski S, Podleśna A (2004) Efficiency of magnetic biostimulation of broad bean cultivated in the experimental plot conditions. Int Agrophys 18(1):65-71

Rochalska M (2002) Magnetic field as a means to improve the vigor of seeds. Acta Agrophys 62:103-111

Rochalska M (2005) Influence of frequent magnetic field on chlorophyll content in leaves of sugar beet plants. Nukleonika 50:25-28

Rybiński W, Patyna H, Przewoźny T (1993) Mutagenic effect of laser and chemical mutagens in barley (Hordeum vulgare L.). Genet Polon 34(4):337-343

Samuilov FD, Garifullina RL (2007) Effect of laser irradiation on microviscosity of aqueous medium in imbibing maize seeds as studied with a spain probe method. Russian J Plant Physiol 54(1):128-131

Simi T, Anjali A, Viswantham Ch, Anil D, Sudipta B (2013) Magnetopriming circumvents the effect of salinity stress in germination in chickpea. Acta Physiol Plant 35:3341-3401

Somogy-Nelson M (1952) Notes on sugar determination. J Biol Chem 19:1-195

Szajsner H, Prośba-Białczyk U, Sacała E, Koszelnik-Leszek A, Szubzda B (2017) The effect of pre-sowing seed stimulation on the germination and pigment content in sugar beet (Beta vulgaris L.) seedlings leaves. Pol. J Nat Sci 32(2):207-222

Vashisth A, Nagarajan S (2010) Effect of germination growth characteristics in sunflower (Helianthus annuus L.) seeds exposed to static magnetic field. J Plant Physiol 167:149-156

Wood AJ, Roper J (2000) A simple and nondestructive technique for measuring plant growth and development. Am Biol Teach 62:215-217

Zepeda-Bautista R, Hernandez-Aguilar C, Suazo-Lopez F, DominguezPachecco AF, Virgen-Varas J, Perez- Reyes C, Peon-Escalante I (2014) Electromagnetic field in corn grain production and health. Afr J Biotechnol 13(1):76-83

Zia U, Haq Jamil Y, Irum S, Randhawa MA, Iqbal M, Amin N (2012) Enhancement in germination, seedling growth and yield of radish (Raphanus sativus) using seed pre-sowing magnetic field treatment. Pol J Environ Stud 21(2):369-374 